Holistik Jurnal Kesehatan, Volume 12, No.4, Oktober 2018: 216-223

\title{
PENYEBARAN VIRUS DENGUE SECARA TRANSOVARIAL PADA VEKTOR DEMAM BERDARAH DENGUE NYAMUK Aedes aegypti
}

\author{
Devita Febriani Putri', Nurhaida Widiani², Debi Arivo ${ }^{3}$
}

\author{
1Dosen Program Studi Pendidikan Dokter, Fakultas Kedokteran Universitas Malahayati Bandar Lampung. \\ Email: devita@malahayati.ac.id \\ 2Dosen Program Studi Pendidikan Biologi, Fakultas Tarbiyah dan Ilmu Keguruan Universitas Islam Negeri Raden \\ Intan Lampung. Email: Nurhaidawidiani@radenintan.ac.id \\ 3Dosen Program Studi Pendidikan Dokter, Fakultas Kedokteran Universitas Malahayati Bandar Lampung. \\ Email: debi@malahayati.ac.id
}

\section{ABSTRACT: TRANSOVARIAL TRANSMISSION OF DENV IN AEDES AEGYPTI}

Background: Transovarial transmission of dengue virus in Aedes aegypti mosquitoes is a vertical transmission of dengue virus infection in female Ae. aegypti mosquitoes to the offspring. The phenomenon of transovarial dengue virus transmission in Dengue Hemorrhagic Fever (DHF) vectors has been proven by laboratory and nature, which indicates the transovarial transmission of dengue virus has an important role in maintaining the dengue epidemic. DHF vector control especially Ae. aegypti mosquitoes is an effective method of stopping transmission and expansion of dengue cases.

Purpose: This scientific article aims to understand the spread of dengue virus transovarially in dengue mosquito vectors, and its relation to the prediction of outbreak dengue cases as information on DHF vector surveillance so that it can make the appropriate control program.

Methods: Collecting several scientific articles to obtain information on the studies that have been done and summarizing the results of the study.

Results: Several result of study are proving that transovarial transmission of dengue virus in Aedes spp. mosquitoes can predict dengue outbreaks case by monitoring the stadium immature Aedes sp., but it need further comprehension statistically about occurrence of dengue outbreaks and the increasing of dengue virus infections in immature stadium of mosquitoes.

Discussion: Transovarial transmission rates from Ae. aegypti mosquito sample obtained from nature may be lower than in the laboratory, because laboratory condition can be controlled in accordande with the development of viruses in mosquito bodies. The dengue virus is proven to be able to spread between stages from eggs, larvae, pupae to imago and $A e$. aegypti mosquitoes can act as reservoirs for dengue virus until the 7 th progeni.

Conclusion: Dispersion dengue virus through transovarial in Ae. aegypti mosquito playing important role in viruses maintained in nature during absence of viremic vertebrata host or when the climate condition are not favorable for that viruses. Continuous monitoring of $A e$. aegypti mosquitoes population vector related the early detection of virus circulation may contribute to the prediction models for dengue outbreaks, so that DHF control can be more effective.

\section{Keywords: Dengue virus, Aedes aegypti, transovarial transmission, Dengue Hemorrhagic Fever}

Pendahuluan: Penularan virus dengue secara transovarial pada nyamuk Aedes aegypti adalah transmisi secara vertikal dari nyamuk $A e$. aegypti betina yang infektif virus dengue kepada keturunannya. Fenomena penularan transovarial virus dengue pada vektor Demam Berdarah Dengue (DBD) telah banyak dibuktikan skala laboratorium dan secara natural di alam, yang mengindikasikan penularan transovarial virus dengue memiliki peranan penting dalam mempertahankan epidemik DBD. Pengendalian vektor DBD khususnya nyamuk $A e$. aegypti merupakan salah satu metode efektif dalam menghentikan penularan dan perluasan kasus DBD.

Tujuan: Studi ini untuk memahami penyebaran virus dengue secara transovarial pada vektor nyamuk DBD, serta kaitannya terhadap prediksi kasus luar biasa (KLB) DBD sebagai informasi surveilans vektor DBD sehingga dapat membuat program pengendalian yang tepat.

Metode: Dengan mengumpulkan beberapa artikel ilmiah untuk mendapatkan informasi studi yang telah dilakukan sebelumnya dan membuat ringkasan dari hasil studi tersebut.

Hasil: Beberapa studi membuktikan penelitian transovarial virus dengue pada nyamuk Aedes spp. dapat memprediksi kasus KLB DBD dengan cara memonitoring stadium immature Aedes sp., namun perlu dilakukan 
Holistik Jurnal Kesehatan, Volume 12, No.4, Oktober 2018: 216-223

PENYEBARAN VIRUS DENGUE SECARA TRANSOVARIAL PADA VEKTOR

DEMAM BERDARAH DENGUE NYAMUK Aedes aegypti

studi statistik lebih lanjut untuk membuktikan hubungan terjadinya KLB DBD dan meningkatnya infeksi virus dengue pada stadium immature nyamuk.

Pembahasan: Angka infeksi penularan transovarial virus dengue dari sampel nyamuk Ae. aegypti yang didapatkan langsung dari alam lebih rendah dari skala laboratorium, dikarenakan kondisi laboratorium dapat dikendalikan sesuai dengan perkembangan virus ditubuh nyamuk. Virus dengue terbukti dapat menyebar antar stadium dari telur, larva, pupa, sampai imago dan nyamuk Ae. aegypti dapat menjadi reservoir virus dengue sampai progeni ke 7 .

Kesimpulan : Penyebaran virus dengue secara transovarial pada nyamuk $A$ e. aegypti berperan penting dalam mempertahankan keberadaan virus di alam khususnya dimana tidak ada hospes vertebrata yang viremik atau ketika keadaan (kondisi iklim) yang tidak menguntungkan virus tersebut di alam. Pemantauan berkelanjutan pada vektor demam berdarah nyamuk Ae. aegypti terkait deteksi dini sirkulasi virus dengue dapat berkontribusi pada pengembangan model prediksi KLB DBD, sehingga pengendalian DBD dapat lebih efektif.

Kata kunci: Virus dengue, Aedes aegypti, penularan transovarial, Demam Berdarah Dengue

\section{PENDAHULUAN}

Demam Berdarah Dengue (DBD) merupakan penyakit tular vektor yang disebabkan virus dengue dan ditularkan melalui nyamuk Aedes spp ke manusia. Penyakit ini menjadi masalah kesehatan dunia baik di negara tropis ataupun subtropis yang menyebabkan kerugian ekonomi yang sangat besar (WHO, 2012).

Virus dengue termasuk virus RNA untai tunggal dan mempunyai empat serotipe yaitu serotipe 1 , serotipe 2 , serotipe 3 , dan serotipe 4 . Keempat tipe virus bersirkulasi di wilayah endemik dengue Asia Tenggara yaitu Malaysia, Thailand, dan Indonesia. Virus dengue serotipe 2 dan virus dengue serotipe 3 lebih sering kasus-kasus Dengue Shock Syndrom (DSS) di Asia Tenggara dibandingkan virus dengue serotipe 1 dan virus dengue serotipe 4 dalam kurun waktu 20 tahun terakhir (Andriyoko et al, 2011; Cucunawangsih \& Lugito, 2017).

Penularan virus secara transovarial adalah transmisi secara vertikal dari nyamuk betina yang infektif virus kepada keturunannya (WHO, 2011). Salah satu cara virus dengue mempertahankan keberadaannya apabila kondisi di alam tidak memungkinkan untuk berkembang biak, melalui penularan transovarial (Angel \& Joshi, 2008; Arunachalam et al, 2008; Günther et al, 2007). Penularan transovarial virus dengue pada nyamuk Aedes sp. telah banyak dibuktikan baik skala laboratorium ataupun pengambilan sampel nyamuk langsung di alam (Arunachalam et al, 2008; Cruz et al, 2015; Le Goff et al, 2011; Günther et al, 2007; Kow et al, 2001; Martínez et al, 2014; Martins et al, 2012; Thavara et al, 2006; Velayutham \& Thenmozhi et al, 2007; Thongrungkiat et al, 2011; Vilela et al, 2010).

Virus dengue juga dapat bertransmisi secara transvovarial dari antar progeni nyamuk $A e$. aegypti. Studi laboratorium oleh Joshi, Mourya, \& Sharma. (2002), membuktikan bahwa penularan transovarial virus dengue serotipe 3 dapat ditularkan pada nyamuk sampai progeny ke 7 , selain itu Rohani et al. (2008) juga membuktikan bahwa virus dengue serotipe 2 dapat terdeteksi pada nyamuk $A$ e. aegypti sampai progeni ke 5 .

Banyaknya fenomena penularan transovarial virus dengue pada vektor DBD, mengindikasikan bahwa penularan transovarial berperan dalam mempertahankan dan meningkatkan epidemik DBD, karena nyamuk bisa bersifat reservoir virus dengue sepanjang hidupnya (Lee \& Rohani, 2005). Pengendalian vektor DBD khususnya nyamuk $A e$. aegypti merupakan salah satu metode efektif dalam menghentikan penularan dan perluasan kasus DBD. Artikel ilmiah ini bertujuan untuk memahami penyebaran virus dengue secara transovarial pada vektor nyamuk DBD, serta kaitannya terhadap prediksi kasus luar biasa DBD sebagai informasi surveilans vektor DBD sehingga dapat membuat program pengendalian vektor yang tepat.

Devita Febriani Putri ${ }^{1}$ Dosen Program Studi Pendidikan Dokter, Fakultas Kedokteran Universitas Malahayati Bandar Lampung. Email: devita@malahayati.ac.id

Nurhaida Widiani² ${ }^{2}$ Dosen Program Studi Pendidikan Biologi, Fakultas Tarbiyah dan IImu Keguruan Universitas Islam Negeri Raden Intan Lampung. Email: Nurhaidawidiani@radenintan.ac.id

Debi Arivo ${ }^{3}$ Dosen Program Studi Pendidikan Dokter, Fakultas Kedokteran Universitas Malahayati Bandar Lampung. Email: debi@malahayati.ac.id 


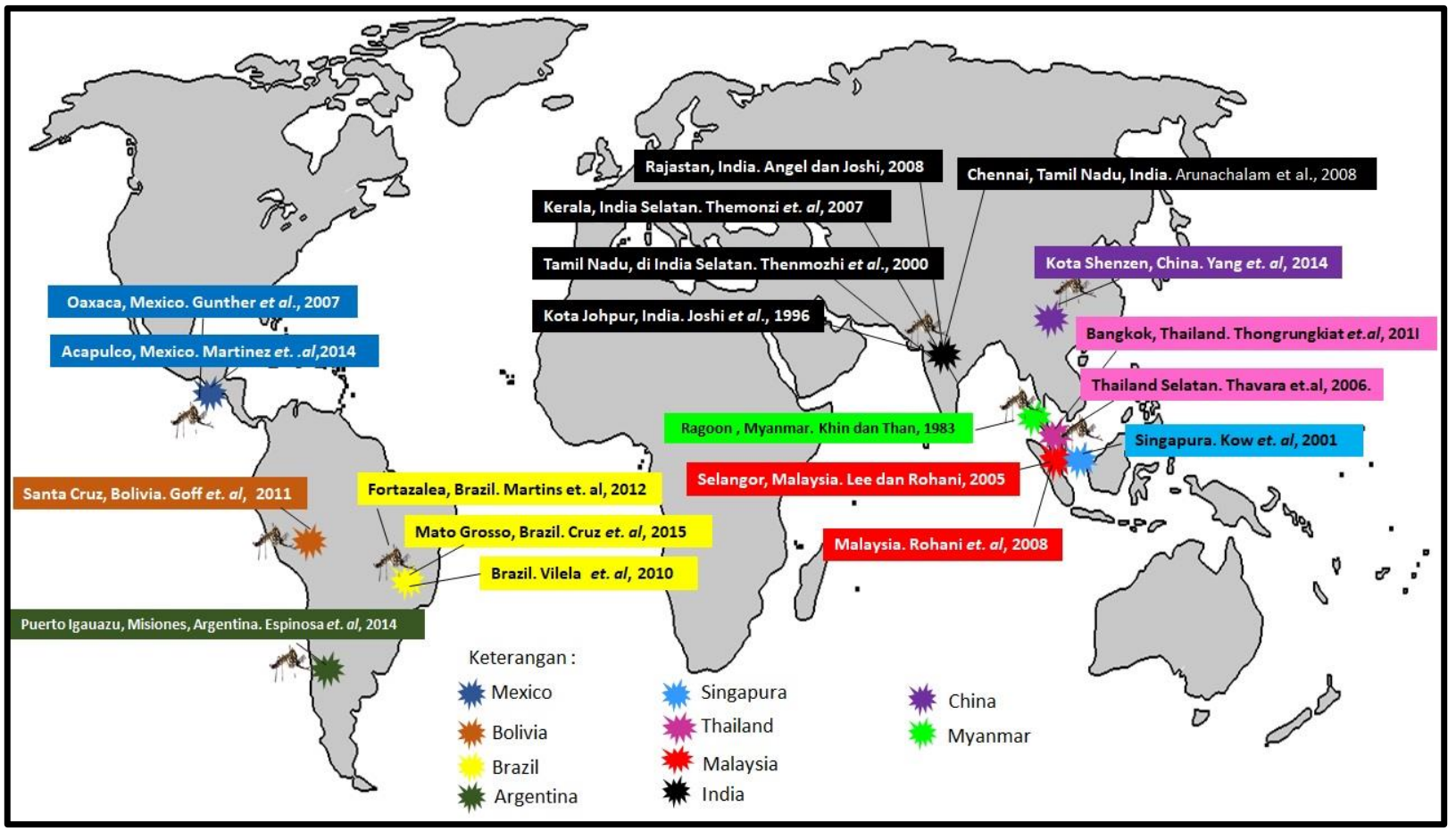

Gambar 1. Peta distribusi penularan transovarial DENV pada populasi nyamuk Aedes sp. di alam tahun $1983-2015$.

Studi tentang penularan transovarial virus dengue pada nyamuk Aedes sp. di alam telah banyak dilakukan, distribusi kasusnya hampir menyebar ke seluruh dunia (Gambar 1). Penelitian transovarial virus dengue tahun 90'an dilakukan oleh Khin dan Than (1983), dengan pengambilan sampel stadium immature (larva) Ae. aegypti di Ragoon, Negara Myanmar.

Metode yang digunakan adalah Metode Direct Fluorecence Antibody Test (DFAT) dengan mendeteksi nyamuk Toxorynchites splendes yang telah diinokulasi dengan DENV-2 yang diisolasi dari Ae. aegypti. Hasil studi adalah terdeteksinya virus dengue seotipe 2 pada larva Ae. aegypti $=$ MIR (0.48/1000) dan Imago Ae. aegypti jantan (kolonisasi dari larva jantan) $=$ MIR $(0.26 / 1000)$. Namun virus dengue tidak terdeteksi pada imago nyamuk betina hasil kolonisasi larva.

Penelitian ini didukung oleh Thenmozhi et al. (2000). menyatakan bahwa virus dengue tidak terdeteksi pada imago hasil kolonisasi larva yang dikoleksi dari Tamil Nadu, India. Sedangkan, penelitian Joshi, Singhi, and Chaudhary (1996) menyatakan sebaliknya, bahwa tidak ada satupun imago nyamuk jantan yang terdeteksi virus dengue, hasil kolonisasi karva di Jodjpur, India.

Beberapa studi selanjutnya membuktikan bahwa virus dengue terdeteksi pada nyamuk $A e$. aegypti jantan di alam. Kow et al. (2001) kali pertama membuktikan DENV terdeteksi pada nyamuk jantan $A e$. aegypti yang ditangkap dari alam di Singapura dengan VIR (Vertical infection rate) $1.33 \%$. Selain itu di Thailand bagian Selatan, Thavara et al. (2006) menyatakan nyamuk $A e$. aegypti jantan yang dikoleksi dari alam, infeksius DENV 2, DENV 3, DENV 4 dan kombinasi DENV 2\&3, dengan VIR 15,2 \%. Arunachalam et al. (2008), di Tamil Nadu India, menyatakan DENV 2 dan DENV 3 terdeteksi pada nyamuk Ae. aegypti jantan yang dikoleksi dari alam, dengan MIR tertinggi 28/1000. DENV 3 juga terdeteksi di nyamuk $A e$. aegypti jantan di Minas Gerais, Brazil dengan MIR 10/1000 (Vilela et al, 2010).

Tahun 2000-an, metode reverse transriptase polymerase chain (RT-PCR) dan enzyme-linked immunosorbent assay (ELISA)

Devita Febriani Putri ${ }^{1}$ Dosen Program Studi Pendidikan Dokter, Fakultas Kedokteran Universitas Malahayati Bandar Lampung. Email: devita@malahayati.ac.id

Nurhaida Widiani ${ }^{2}$ Dosen Program Studi Pendidikan Biologi, Fakultas Tarbiyah dan IImu Keguruan Universitas Islam Negeri Raden Intan Lampung. Email: Nurhaidawidiani@radenintan.ac.id

Debi Arivo ${ }^{3}$ Dosen Program Studi Pendidikan Dokter, Fakultas Kedokteran Universitas Malahayati Bandar Lampung. Email: debi@malahayati.ac.id 
Holistik Jurnal Kesehatan, Volume 12, No.4, Oktober 2018: 216-223

\section{PENYEBARAN VIRUS DENGUE SECARA TRANSOVARIAL PADA VEKTOR}

DEMAM BERDARAH DENGUE NYAMUK Aedes aegypti

mulai digunakan untuk mendeteksi virus denge pada nyamuk, menggantikan metode imunologi (Grunnill and Boots 2016). Hanya studi yang dilakukan Rohani et al. (2007) yang membandingkan metode pengujian transovarial virus dengue di nyamuk. Metode sel kultur C6/36 dibandingkan dengan RT-PCR untuk mendeteksi DENV dari larva Ae. aegypti dan Ae. albopictus yang tertangkap dari alam (tempat perkembangbiakan) di Malaysia.

Hasil yang didapatkan adalah metode sel kultur C6/36 dan RT-PCR dapat digunakan untuk mendeteksi DENV dari larva nyamuk. Sel kultur C6/36 dapat mendeteksi virus dengue dengan angka infeksi yang lebih tinggi (28\%) dibandingkan metode RT-PCR (9.5\%), namun dari segi kecepatan pengujian, RT-PCR lebih efektif untuk mendeteksi virus dengue pada larva nyamuk yang dikoleksi dari alam.

Di Indonesia, studi tentang penularan transovarial virus dengue pada nyamuk $A e$. aegypti di alam pertama kali dilakukan oleh Umniyati (2004) di Kelurahan Klitren Yogyakarta, dengan metode Imunositokimia Streptavidin Biotin Peroxidase Complex (ISBPC) pada sediaan pencet kepala (head squash) nyamuk dengan Transovarial Infection Rate (TIR) sebesar 27,27\%. Penyebaran virus secara transovarial pada sampel nyamuk $A e$. aegypti di alam juga telah dibuktikan di negara Mexico, Bolivia, Argentina, dan China.

\section{PENYEBARAN VIRUS DENGUE MELALU PROGENI DAN STADIUM NYAMUK Aedes aegypti SECARA TRANSOVARIAL}

Tabel 1. Penularan Transovarial Virus Dengue melalui Progeni dan Stadium Nyamuk Aedes aegypti Skala Laboratorium

\begin{tabular}{|c|c|c|c|c|}
\hline Pustaka & $\begin{array}{l}\text { Serotipe Virus } \\
\text { Dengue }\end{array}$ & Spesies Vektor & Angka Infeksi & $\begin{array}{l}\text { Metode Infeksi pada F0/ } \\
\text { Metode Screening }\end{array}$ \\
\hline $\begin{array}{l}\text { Joshi dan Sharma, } \\
2001\end{array}$ & DENV 3 & $\begin{array}{l}\text {-Ae. aegypti F0 ke F1 } \\
\text {-Ae. aegypti F1 ke F2 } \\
\text {-Ae. aegypti F2 ke F3 } \\
\text {-Ae. aegypti F3 ke F4 } \\
\text {-Ae. aegypti F4 ke F5 } \\
\text {-Ae. aegypti F5 ke F6 } \\
\text {-Ae. aegypti F6 ke F7 }\end{array}$ & $\begin{array}{l}\text { - VIR }(52 \%) \\
\text { - VIR }(55.6 \%) \\
\text { - VIR }(55.6 \%) \\
\text { - VIR }(30.7 \%) \\
\text { - VIR }(23.0 \%) \\
\text { - VIR }(15.5 \%) \\
\text { - VIR }(2.8 \%)\end{array}$ & $\begin{array}{lr}\text { Metode } & \text { inokulasi } \\
\text { intratorakal/ Metode IFAT }\end{array}$ \\
\hline Joshi et al., 2002. & DENV 3 & $\begin{array}{l}\text { Ae. aegypti P ke F1 } \\
\text {-Ae. aegypti F1 ke F2 } \\
\text {-Ae. aegypti F2 ke F3 } \\
\text {-Ae. aegypti F3 ke F4 } \\
\text {-Ae. aegypti F4 ke F5 } \\
\text {-Ae. aegypti F5 ke F6 } \\
\text {-Ae. aegypti F6 ke F7 }\end{array}$ & $\begin{array}{l}\text { - VIR }(2.8 \%) \\
\text { - VIR }(8.6 \%) \\
\text { - VIR }(13 \%) \\
\text { - VIR }(11.7 \%) \\
\text { - VIR }(11.6 \%) \\
\text { - VIR }(11.7 \%) \\
\text { - VIR }(12.6 \%)\end{array}$ & $\begin{array}{l}\text { Metode inokulasi } \\
\text { intratorakal/ Metode IFAT }\end{array}$ \\
\hline $\begin{array}{l}\text { Wasinpiyamongkol } \\
\text { et al., } 2003\end{array}$ & DENV 2 & $\begin{array}{l}\text { Ae. aegypti } \\
\text { Pale Parental/P } \\
\text { Pale P ke F1 } \\
\text { Dark Parental/P } \\
\text { Dark P ke F1 } \\
\text { Dark F1 ke F2 } \\
\text { Dark F2ke F3 }\end{array}$ & $\begin{array}{l}-\operatorname{IR}(26.82 \%) \\
-\operatorname{FIR}(2.7 \%) \\
-\operatorname{IR}(20.63 \%) \\
-\operatorname{FIR}(3.7 \%) \\
-\operatorname{FIR}(3.3 \%) \\
-\operatorname{FIR}(1.4 \%)\end{array}$ & $\begin{array}{l}\text { Metode inokulasi } \\
\text { oral/Metode IFAT }\end{array}$ \\
\hline
\end{tabular}

Devita Febriani Putri ${ }^{1}$ Dosen Program Studi Pendidikan Dokter, Fakultas Kedokteran Universitas Malahayati Bandar Lampung. Email: devita@malahayati.ac.id

Nurhaida Widiani2 ${ }^{2}$ Dosen Program Studi Pendidikan Biologi, Fakultas Tarbiyah dan IImu Keguruan Universitas Islam Negeri Raden Intan Lampung. Email: Nurhaidawidiani@radenintan.ac.id

Debi Arivo ${ }^{3}$ Dosen Program Studi Pendidikan Dokter, Fakultas Kedokteran Universitas Malahayati Bandar Lampung. Email: debi@malahayati.ac.id 
Holistik Jurnal Kesehatan, Volume 12, No.4, Oktober 2018: 216-223

PENYEBARAN VIRUS DENGUE SECARA TRANSOVARIAL PADA VEKTOR DEMAM BERDARAH DENGUE NYAMUK Aedes aegypti

\begin{tabular}{|c|c|c|c|c|}
\hline Rohani et al., 2008. & DENV 2 & $\begin{array}{l}\text {-Ae. aegypti } \mathrm{P} \text { ke F1 } \\
\text {-Ae. aegypti F1 ke F2 } \\
\text {-Ae. aegypti F2 ke F3 } \\
\text {-Ae. aegypti F3 ke F4 } \\
\text {-Ae. aegypti F4 ke F5 }\end{array}$ & $\begin{array}{l}-M I R(45 / 1000) \\
-M I R(45 / 1000) \\
-M I R(35 / 1000) \\
-M I R(35 / 1000) \\
-M I R(30 / 1000)\end{array}$ & $\begin{array}{l}\text { Metode Inokulasi Oral/ } \\
\text { Metode Kultur Sel lalu } \\
\text { diwarnai dengan PAP }\end{array}$ \\
\hline Seran, 2010 & DENV 2 & $\begin{array}{l}\text {-Telur Ae. aegypti } \\
\text {-Larva Ae. aegypti } \\
\text {-Pupa Ae. aegypti } \\
\text {-Imago Ae. aegypti }\end{array}$ & $\begin{array}{l}\operatorname{TIR}(56 \%) \\
\operatorname{TIR}(22 \%) \\
\operatorname{TIR}(36 \%) \\
\operatorname{TIR}(96 \%)\end{array}$ & $\begin{array}{lr}\text { Metode Inokulasi } \\
\text { Oral/Metode } \\
\text { dikonfirmasi dengan PCR }\end{array}$ \\
\hline
\end{tabular}

\begin{abstract}
Beberapa studi laboratorium berhasil mendemontrasikan virus dengue dapat mempertahankan keberadaannya antar progeni dan stadium nyamuk (Tabel 1). Joshi and Sharma (2001), melakukan studi di India untuk mengetahui dampak penularan transovarioal virus dengue serotipe 3 ketahanan nyamuk Ae. aegypti. Hasil fertilitas telur yang didapatkan dari progeny F1 sampai F6 menunjukkan kegagalan menetas berkisar $30 \%-68.1 \%$.
\end{abstract}

Keberadaan virus pada nyamuk mengurangi ketahanan telur pada progeni selanjutnya. Studi ini menyimpulkan virus dengue mempertahankan hidupnya dalam jumlah optimal melalui penularan transovarial kepada populasi nyamuk yang memiliki keunggulan secara genetik, dimana populasi tersebut sangat penting dalam dinamika penularan dengue. Studi dilanjutkan oleh Joshi, Mourya, and Sharma (2002) untuk menguji ketahanan virus dengue serotipe 3 melalui penularan transovarial pada 7 generasi berturut turut nyamuk $A$ e. aegypti. Joshi et al. berhasil membuktikan virus dengue serotipe 3 dapat ditularkan secara transovarial sampai pada progeni ke 7 , dan terjadi peningkatan jumlah virus serotipe 3 pada F1 nyamuk yang positif (VIR 2.8\%) hingga F2 (13\%), kemudian stabil pada generasi selanjutnya (F3-F7).

Hasil studi juga menyatakan kematian pada stadium larva dan dewasa yang infeksius virus dengue 3 secara transovarial lebih banyak dibandingkan kontrol, dan mengindikasikan kesuburan dan fekunditas pada telur yang infeksius transovarial DENV 3 lebih rendah, dibandingkan telur yang non infeksius.

Wasinpiyamongkol et al. (2003), melalukan studi di Thailand tentang penularan transovarial DENV pada nyamuk Ae. aegypti di Thailand berdasarkan variasi morfologi (dark form dan pale form) dari nyamuk Ae. aegypti, dan menyatakan penularan transovarial virus dengue serotipe 3 pada nyamuk dark form Ae. aegypti progeninya terdeteksi sampai generasi F3 untuk, sedangkan untuk pale form Ae. aegypti progeninya terdeteksi sampai F1. FIR mengalami penurunan dari progeni ke progeni. Penularan transovarial (FIR) pada kedua progeni morfologi nyamuk (pale dan dark form) hampir sama.

Rohani et al. (2008) melakukan studi yang mirip dengan Joshi et al., tetap virus yang digunakan adalah serotipe 2. Hasil studi adalah virus dengue serotipe 2 terdeteksi positif sampai progeni ke 5 dengan MIR yang menurun (45/100030/1000), daan negatif pada generasi ke 6 dan ke 7. Studi ini mengindikasikan virus dengue dapat ditularkan secara transovarial antar progeni berturut - turut, hal ini memungkinkan nyamuk dapat menjadi reservoir alami bagi virus dengue. Pernyataan bukti penularan transovarial virus dengue serotipe 2 pada nyamuk, didukung dengan studi penyebaran virus dengue antar stadium nyamuk Ae. aegypti, dibuktikan oleh Seran (2010) di Yogyakarta Indonesia. Seran membuktikan bahwa progeni F2 nyamuk Ae. aegypti terdeteksi positif virus dengue serotipe 2 , dimana parental telah diinokulasikan virus dengue serotipe 2 secara oral, dan menurunkan virus ke stadium keturunannya dengan presentase TIR tertinggi pada stadium imago (96\%), lalu stadium telur $(56 \%)$, kemudian stadium pupa (36\%), dan terakhir stadium larva (22\%).

PREDIKSI KEJADIAN LUAR BIASA DBD MELALUI STADIUM IMMATURE NYAMUK VEKTOR

Devita Febriani Putri ${ }^{1}$ Dosen Program Studi Pendidikan Dokter, Fakultas Kedokteran Universitas Malahayati Bandar Lampung. Email: devita@malahayati.ac.id

Nurhaida Widiani ${ }^{2}$ Dosen Program Studi Pendidikan Biologi, Fakultas Tarbiyah dan IImu Keguruan Universitas Islam Negeri Raden Intan Lampung. Email: Nurhaidawidiani@radenintan.ac.id

Debi Arivo ${ }^{3}$ Dosen Program Studi Pendidikan Dokter, Fakultas Kedokteran Universitas Malahayati Bandar Lampung. Email: debi@malahayati.ac.id 
Holistik Jurnal Kesehatan, Volume 12, No.4, Oktober 2018: 216-223

PENYEBARAN VIRUS DENGUE SECARA TRANSOVARIAL PADA VEKTOR

DEMAM BERDARAH DENGUE NYAMUK Aedes aegypti

Beberapa hasil studi membuktikan penelitian transovarial virus dengue dapat memprediksi kasus KLB DBD dengan cara memonitoring stadium immature Aedes sp. (Lee and Rohani 2005) meneliti hubungan penularan transovarial virus dengue pada nyamuk $A$ e. aegypti dan nyamuk $A e$. albopictus dengan kemunculan (outbreak) dengue di area perkotaan Selangor, Malaysia dengan membandingkan data virus dengue secara transovarial pada larva dengan data kasus dengue pada area penelitian. Hasil studi adalah ketika kasus dengue dan penularan transovarial virus dengue pada nyamuk $A e$. albopictus dianalisis bersamaan, dilaporkan penularan transovarial virus dengue terdeteksi positif terjadi sebelum laporan kasus dengue positif pada manusia dan interval antara penularan transovarial virus dengan kasus pertama pada manusia adalah $7-41$ hari.

Pernyataan ini didukung oleh, Thongrungkiat et al. (2011) menyatakan tingkat infeksi virus dengue secara transovarial tertinggi diperoleh 4 bulan sebelum puncak transmisi DBD pada manusia, yang menunjukkan pentingnya pemantauan staium immature nyamuk $A e$. aegypti. Stadium immature nyamuk dari lingkungan alami serta informasi dari dengue-GIS berpotensi dalam mengindentifikasi penyebaran kasus luar biasa dengue lebih dini yang berguna untuk melengkapi sistem kewaspadaan dini pada KLB DBD selama periode inter epidemik (Martins et al, 2012; Thongrungkiat et al, 2011).

\section{SIMPULAN}

Penyebaran virus dengue secara transovarial pada nyamuk Ae. aegypti berperan penting dalam mempertahankan keberadaan virus di alam khususnya dimana tidak ada host vertebrata yang viremik atau ketika keadaan (kondisi iklim) yang tidak menguntungkan virus tersebut di alam. Angka infeksi penularan transovarial virus dengue dari sampel nyamuk $A e$. aegypti yang didapatkan langsung dari alam lebih rendah dari skala laboratorium, dikarenakan kondisi laboratorium dapat dikendalikan sesuai dengan perkembangan virus ditubuh nyamuk. Virus dengue terbukti dapat menyebar antar stadium dari telur, larva, pupa, sampai imago.
Nyamuk Ae. aegypti dapat menjadi reservoir virus dengue sampai progeni ke 7 , yang mengindikasikan bahwa penularan transovarial virus dengue berperan dalam mempertahankan epidemik DBD.

Perlu dilakukan studi lebih lanjut untuk membuktikan hubungan terjadinya kejadian luar biasa DBD dan meningkatnya infeksi virus dengue pada stadium immature nyamuk. Pemantauan berkelanjutan pada vektor demam berdarah nyamuk $A e$. aegypti terkait deteksi dini sirkulasi virus dengue dapat berkontribusi pada pengembangan model prediksi KLB DBD, sehingga pengendalian DBD dapat lebih efektif.

\section{DAFTAR PUSTAKA}

Andriyoko, B., Parwati, I., Tjandrawati, A., \& Lismayanti, L. (2012). Penentuan serotipe virus dengue dan gambaran manifestasi klinis serta hematologi rutin pada infeksi virus dengue. Majalah Kedokteran Bandung, 44(4), 253-260.

Arunachalam, N., Tewari, S. C., Thenmozhi, V., Rajendran, R., Paramasivan, R., Manavalan, R., ... \& Tyagi, B. K. (2008). Natural vertical transmission of dengue viruses by Aedes aegypti in Chennai, Tamil Nadu, India. Indian Journal of Medical Research, 127(4), 395.

Cucunawangsih, \& Lugito, N. P. H. (2017). Trends of dengue disease epidemiology. Virology: research and treatment, 8, $1178122 X 17695836$.

Grunnill, M., \& Boots, M. (2015). How important is vertical transmission of dengue viruses by mosquitoes (Diptera: Culicidae)?. Journal of medical entomology, 53(1), 1-19.

Günther, J., Martínez-Muñoz, J. P., PérezIshiwara, D. G., \& Salas-Benito, J. (2007). Evidence of vertical transmission of dengue virus in two endemic localities in the state of Oaxaca, Mexico. Intervirology, 50(5), 347352.

Devita Febriani Putri ${ }^{1}$ Dosen Program Studi Pendidikan Dokter, Fakultas Kedokteran Universitas Malahayati Bandar Lampung. Email: devita@malahayati.ac.id

Nurhaida Widiani ${ }^{2}$ Dosen Program Studi Pendidikan Biologi, Fakultas Tarbiyah dan IImu Keguruan Universitas Islam Negeri Raden Intan Lampung. Email: Nurhaidawidiani@radenintan.ac.id

Debi Arivo ${ }^{3}$ Dosen Program Studi Pendidikan Dokter, Fakultas Kedokteran Universitas Malahayati Bandar Lampung. Email: debi@malahayati.ac.id 
Holistik Jurnal Kesehatan, Volume 12, No.4, Oktober 2018: 216-223

\section{PENYEBARAN VIRUS DENGUE SECARA TRANSOVARIAL PADA VEKTOR}

DEMAM BERDARAH DENGUE NYAMUK Aedes aegypti

Joshi, V., \& Sharma, R. C. (2001).Impact of Vertically-Transmitted Dengue Virus on Viability of Eggs of Virus-Inoculated Aedes aegypti.

Joshi, V., Mourya, D. T., \& Sharma, R. C. (2002). Persistence of dengue-3 virus through transovarial transmission passage in successive generations of Aedes aegypti mosquitoes. The American journal of tropical medicine and hygiene, 67(2), 158161.

Joshi, V., Singhi, M., \& Chaudhary, R. C. (1996). Transovarial transmission of dengue 3 virus by Aedes aegypti. Transactions of the Royal Society of Tropical Medicine and Hygiene, 90(6), 643-644.

Khin, M. M., \& Than, K. A. (1983). Transovarial transmission of dengue 2 virus by Aedes aegypti in nature. The American journal of tropical medicine and hygiene, 32(3), 590594.

Kow, C. Y., Koon, L. L., \& Yin, P. F. (2001). Detection of dengue viruses in field caught male Aedes aegypti and Aedes albopictus (Diptera: Culicidae) in Singapore by typespecific PCR. Journal of medical entomology, 38(4), 475-479.

Lee, H. L., \& Rohani, A. (2005). Transovarial transmission of dengue virus in Aedes aegypti and Aedes albopictus in relation to dengue outbreak in an urban area in Malaysia.

Martínez, N. E., Dzul-Manzanilla, F., GutiérrezCastro, C., Ibarra-López, J., Bibiano-Marín, W., López-Damián, L., ... \& Manrique-Saide, P. (2014). Natural vertical transmission of dengue-1 virus in Aedes aegypti populations in Acapulco, Mexico. Journal of the American Mosquito Control Association, 30(2), 143-146.
Martins, V. E. P., Alencar, C. H., Kamimura, M. T., de Carvalho Araujo, F. M., De Simone, S. G., Dutra, R. F., \& Guedes, M. I. F. (2012). Occurrence of natural vertical transmission of dengue-2 and dengue- 3 viruses in Aedes aegypti and Aedes albopictus in Fortaleza, Ceará, Brazil. PloS one, 7(7), e41386.

Rohani, A., Zamree, I., Joseph, R. T., \& Lee, H. L. (2008). Persistency of transovarial dengue virus in Aedes aegypti (Linn.). Southeast Asian J Trop Med Public Health, 39(5), 813816.

Rohani, A., Zamree, I., Lee, H. L., Mustafakamal, I., Norjaiza, M. J., \& Kamilan, D. (2007). Detection of transovarial dengue virus from field-caught Aedes aegypti and Ae. albopictus larvae using $C$.

Seran, M. D. (2010). Uji laboratorium penularan trans-stadial virus dengue pada stadium telur, larva, pupa dan imago dari nyamuk aedes aegypti (Diptera Culicidae) (Master's thesis, Universitas Gadjah Mada).

Thavara, U., Siriyasatien, P., Tawatsin, A., Asavadachanukorn, P., Anantapreecha, S., Wongwanich, R., \& Mulla, M. S. (2006). Double infection of heteroserotypes of dengue viruses in field populations of Aedes aegypti and Aedes albopictus (Diptera: Culicidae) and serological features of dengue viruses found in patients in southern Thailand. Southeast Asian journal of tropical medicine and public health, 37(3), 468.

Thenmozhi, V., Hiriyan, J. G., Tewari, S. C., Samuel, P. P., Paramasivan, R., Rajendran, R., ... \& Tyagi, B. K. (2007). Natural vertical transmission of dengue virus in Aedes albopictus (Diptera: Culicidae) in Kerala, a southern Indian state. Japanese journal of infectious diseases, 60(5), 245.

Thenmozhi, V., Tewari, S. C., Manavalan, R., Balasubramanian, A., \& Gajanana, A. (2000). Natural vertical transmission of dengue viruses in Aedes aegypt in southern India. Transactions of the Royal Society of Tropical Medicine and Hygiene, 94(5), 507.

Devita Febriani Putri ${ }^{1}$ Dosen Program Studi Pendidikan Dokter, Fakultas Kedokteran Universitas Malahayati Bandar Lampung. Email: devita@malahayati.ac.id

Nurhaida Widiani ${ }^{2}$ Dosen Program Studi Pendidikan Biologi, Fakultas Tarbiyah dan IImu Keguruan Universitas Islam Negeri Raden Intan Lampung. Email: Nurhaidawidiani@radenintan.ac.id

Debi Arivo ${ }^{3}$ Dosen Program Studi Pendidikan Dokter, Fakultas Kedokteran Universitas Malahayati Bandar Lampung. Email: debi@malahayati.ac.id 


\section{PENYEBARAN VIRUS DENGUE SECARA TRANSOVARIAL PADA VEKTOR}

\section{DEMAM BERDARAH DENGUE NYAMUK Aedes aegypti}

Thongrungkiat, S., Maneekan, P., Wasinpiyamongkol, L., \& Prummongkol, S. (2011). Prospective field study of transovarial dengue-virus transmission by two different forms of Aedes aegypti in an urban area of Bangkok, Thailand. Journal of Vector Ecology, 36(1), 147-152.

Umniyati, S.R. (2004). Preliminary Investigation on The Transovarial Transmission of Dengue Virus in The Populatian of Ae. aegypti in the Well. Makalah disajikan dalam Seminar Peringatan Hari Nyamuk IV. Surabaya.

Vilela, A. P., Figueiredo, L. B., dos Santos, J. R., Eiras, Á. E., Bonjardim, C. A., Ferreira, P. C., \& Kroon, E. G. (2010). Dengue virus 3 genotype $I$ in Aedes aegypti mosquitoes and eggs, Brazil, 2005-2006. Emerging infectious diseases, 16(6), 989.
Wasinpiyamongkol, L., Thongrungkiat, S., Jirakanjanakit, N., \& Apiwathnasorn, C. (2003). Susceptibility and transovarial transmission of dengue virus in Aedes aegypti: a preliminary study of morphological variations. Southeast Asian journal of tropical medicine and public health, 34, 131-135.

World Health Organization. (2009). Special Programme for Research, Training in Tropical Diseases, World Health Organization. Department of Control of Neglected Tropical Diseases, World Health Organization. Epidemic, \& Pandemic Alert. (2009). Dengue: guidelines for diagnosis, treatment, prevention and control.

World Health Organization. (2011). Comprehensive guideline for prevention and control of dengue and dengue haemorrhagic fever.

Devita Febriani Putri ${ }^{1}$ Dosen Program Studi Pendidikan Dokter, Fakultas Kedokteran Universitas Malahayati Bandar Lampung. Email: devita@malahayati.ac.id

Nurhaida Widiani ${ }^{2}$ Dosen Program Studi Pendidikan Biologi, Fakultas Tarbiyah dan IImu Keguruan Universitas Islam Negeri Raden Intan Lampung. Email: Nurhaidawidiani@radenintan.ac.id

Debi Arivo ${ }^{3}$ Dosen Program Studi Pendidikan Dokter, Fakultas Kedokteran Universitas Malahayati Bandar Lampung. 